\title{
Effect of titanium and nitrogen on the transformation characteristics of acicular ferrite in reheated $\mathrm{C}-\mathrm{Mn}$ steel weld metals
}

\author{
M. N. Ilman • R. C. Cochrane • G. M. Evans
}

Received: 3 October 2012 / Accepted: 7 August 2013 / Published online: 25 August 2013

(C) The Author(s) 2013. This article is published with open access at Springerlink.com

\begin{abstract}
The nucleation and growth processes of acicular ferrite in C-Mn steel weld metals containing various levels of titanium and nitrogen have been studied using dilatometry combined with transmission electron microscopy associated with energy-dispersive X-ray analysis. The as-deposited weld metals were thermally cycled under continuous cooling conditions, and fully developed and partially transformed microstructures were studied. Results showed that austenite transformed to ferrite in titanium-free $\mathrm{C}-\mathrm{Mn}$ steel weld metals over a comparatively large range, and the resulting microstructure was dominated by Widmanstatten ferrite. The addition of titanium, typically $410 \mathrm{ppm}$, to C-Mn steel weld metals was found to accelerate the transformation kinetics, reducing the range in transformation temperature and modifying the weld microstructure with Widmanstatten ferrite being replaced by intragranularly nucleated acicular ferrite. Subsequent additions of nitrogen of around $240 \mathrm{ppm}$ to $\mathrm{C}-\mathrm{Mn}$ and $\mathrm{C}-\mathrm{Mn}-\mathrm{Ti}$ inhibited the transformation, but this soluble nitrogen had a little effect on weld microstructure. It is concluded that the development of acicular ferrite in $\mathrm{C}-\mathrm{Mn}-\mathrm{Ti}-\mathrm{N}$ steel weld metals is associated with TiO- and TiN-type inclusions which act as effective sites for nucleation of acicular ferrite.
\end{abstract}

Doc. IIW-2407, recommended for publication by Commission II "Arc Welding and Filler Metals."

\footnotetext{
M. N. Ilman

Department of Mechanical and Industrial Engineering,

Gadjah Mada University, Yogyakarta, Indonesia

e-mail: ilman_noer@ugm.ac.id

R. C. Cochrane · G. M. Evans ( $₫)$

University of Leeds, Leeds, UK

e-mail: gmevans@globalnet.co.uk

R. C. Cochrane

e-mail: r.cochrane.cochrane@btinternet.com
}

This finding illustrates the possibility of using nitrogen as a deliberate alloying addition under some circumstances.

Keywords Acicular ferrite · Ti-N type weld metal $\cdot$ Phase transformation $\cdot$ Inclusion

\section{Introduction}

A class of C-Mn weld metal which provides a good combination of strength and impact toughness results from alloying with titanium due to the formation of a fine interlocking acicular ferrite microstructure. This type of weld metal has been the subject of numerous research studies. It is reported that the role of titanium in nucleating acicular ferrite is associated with inclusions containing $\mathrm{TiO}[1-8], \mathrm{MnOTiO}_{2}[9], \mathrm{Ti}_{2} \mathrm{O}_{3}[10$, 11] and TiN [12-15]. According to a lattice disregistry model which takes into account the mismatch between the inclusion surface and ferrite matrix, phases such as $\mathrm{TiO}, \mathrm{TiO}_{2}$ and $\mathrm{TiN}$ have low mismatch values, typically $3.0,8.8$ and $3.8 \%$, respectively, giving effective sites for nucleation of acicular ferrite $[5,16]$. Evans [17] has systematically studied the effect of titanium in the absence of aluminium on $\mathrm{C}-\mathrm{Mn}$ steel weld metals with the results showing that a small addition of titanium, typically $30 \mathrm{ppm}$, to C-Mn steel weld metal is sufficient to produce acicular ferrite. This dramatic microstructural change (could be linked) appears to result from changes in the inclusion chemistry from $\mathrm{MnO} \cdot \mathrm{SiO}_{2}$ to $\mathrm{MnO} \cdot \mathrm{Ti}_{2} \mathrm{O}_{3}$ [18].

Nitrogen is usually not considered as an alloying element, but it occurs universally in steel products, and a low level of nitrogen can exert large effects. Some of these effects are detrimental, often being associated with embrittlement; therefore, the amount of nitrogen is usually maintained low, typically less than 200 ppm [19]. In steel weld metals, the effects of nitrogen are usually associated with poor weld metal 
toughness and strain age embrittlement [20]. However, the role of nitrogen in steel weld metals has gained significant attention, recently [14, 21-23], and this may be due to the fact that nitrogen addition is inexpensive. In most cases, the beneficial effects of nitrogen are the result of an interaction with alloying elements present.

Acicular ferrite is formed during austenite to ferrite phase transformation as a result of a succession of competing nucleation and growth processes at grain boundary and intragranular sites. Where grain boundary sites predominate, Widmanstatten ferrite is formed preferentially, whereas rapid development of intragranular sites tends to favour acicular ferrite. Unfortunately, it is almost impossible to measure transformation kinetics directly during the welding process so that the most appropriate method used in the present investigation is to simulate weld metal transformation dilatometrically using samples taken from as-deposited weld metals. In dilatometric studies, transformation-start temperature $\left(T_{\mathrm{s}}\right)$ is generally designates the start of grain boundary ferrite formation, whereas the $50 \%$ transformation temperature $\left(T_{50}\right)$ and peak rate transformation temperature $\left(T_{\mathrm{PRTT}}\right)$ can be used as an indication of transformation kinetics of acicular ferrite [3, 24]. The temperature range for nucleation of acicular ferrite has been found to be $600-680{ }^{\circ} \mathrm{C}$, depending on the chemical composition and cooling rate of steel weld metals $[24,25]$. However, phase transformations in steel weld metals are complex, involving factors such as chemical composition, inclusions, prior austenite grain size and cooling rate.

Referring to the above studies, it seems that the transformation behaviour of $\mathrm{C}-\mathrm{Mn}-\mathrm{Ti}-\mathrm{N}$ weld metals, in particular nucleation and growth processes of acicular ferrite, is still far from fully understood and, therefore, is the subject of the present investigation.

\section{Experimental procedures}

\subsection{Materials}

The MMA samples were prepared by Oerlikon-Welding Limited, Zurich, Switzerland, according to ISO 2560-1973. Details of sample preparation are given elsewhere [17]. Weld metal specimens with different levels of titanium (designated as $\mathrm{O}$ and $\mathrm{X}$ ) and nitrogen ( $\mathrm{N}$ and $\mathrm{N} 2$ ) were deposited with their chemical compositions which are given in Table 1.

Two types of synthetic samples were produced in a vacuum arc furnace, using pure $\mathrm{Fe}$, Ti and graphite components with and without nitrogen additions melted to form small rods of approximately $6 \mathrm{~mm}$ diameter and $25 \mathrm{~mm}$; from previous studies, the cooling rate during solidification was $\sim 10{ }^{\circ} \mathrm{C} / \mathrm{s}$, corresponding to the weld metals above.
Table 1 Chemical composition of C-Mn-Ti-N steel weld metals

\begin{tabular}{cllllllllll}
\hline Weld & $\begin{array}{l}\mathrm{C} \\
\text { wt } \%\end{array}$ & Mn & Si & S & P & $\begin{array}{l}\text { Ti } \\
\mathrm{ppm}\end{array}$ & $\mathrm{B}$ & $\mathrm{N}$ & $\mathrm{O}$ \\
$\mathrm{N}$ & & & & & & & & & \\
$\mathrm{O}$ & 0.074 & 1.40 & 0.25 & 0.008 & 0.007 & 1 & 1 & 79 & 475 \\
$\mathrm{X}$ & 0.069 & 1.47 & 0.45 & 0.005 & 0.006 & 410 & 2 & 77 & 282 \\
$\mathrm{~N} 2$ & & & & & & & & & \\
$\mathrm{O} 2$ & 0.073 & 1.66 & 0.27 & 0.009 & 0.008 & 5 & 5 & 235 & 399 \\
$\mathrm{X} 2$ & 0.068 & 1.46 & 0.47 & 0.007 & 0.006 & 450 & 2 & 249 & 297 \\
\hline
\end{tabular}

These samples are referred to as $\mathrm{C}-\mathrm{Mn}-\mathrm{Ti}$ and $\mathrm{C}-\mathrm{Mn}-\mathrm{Ti}-$ $\mathrm{N}$ alloys in the text below.

\subsection{Dilatometry}

A dilatometric technique was used to study the $\gamma \rightarrow \alpha$ phase transformation of $\mathrm{C}-\mathrm{Mn}-\mathrm{Ti}-\mathrm{N}$ weld metals during continuous cooling. Specimens were machined in the form of hollow cylinders with standard specimen dimensions, i.e. $10 \mathrm{~mm}$ long by $5 \mathrm{~mm}$ outside diameter with a wall thickness of $1 \mathrm{~mm}$. The axis of each specimen was parallel to the weld direction. The specimens were subjected to controlled thermal cycles which consisted of austenitisation at $1,250^{\circ} \mathrm{C}$ for 2 min followed by continuous cooling at two different weld cooling rates of 13 and $25^{\circ} \mathrm{C} / \mathrm{s}$ from 800 to $500{ }^{\circ} \mathrm{C}$.

Figure 1 shows an example of dilatation curve obtained during continuous cooling. In this figure, the straight lines marked CL and DK are the extensions of the dilatation curve, and they represent austenite phase (lower line DK) and transformation products (upper line CL). The $T_{\mathrm{s}}$ can be determined by locating the temperature at which the dilatation curve starts to deviate. In this investigation, $T_{\mathrm{s}}$ is determined, as $1 \%$ austenite has transformed into ferrite by drawing a dotted line parallel to BK, off-set to $1 \%$ of the line $\mathrm{F}$, until the line intersects the dilatation curve at $T_{\mathrm{s}}$. Similarly, the value of $T_{\mathrm{f}}$ is taken at $99 \%$ of austenite transformed. $T_{\text {PRTT }}$ occurs at the inflection point of the dilatation curve where the first derivative, i.e. $\mathrm{d}(\Delta \mathrm{L} / \mathrm{L}) / \mathrm{dT}$, at this point is maximum. By applying the lever rule, the fraction of austenite transformed to ferrite is given by the expression $f=\mathrm{OG} / \mathrm{OH}$. These experimental conditions are aimed to simulate the austenite grain size and cooling rates experienced by the original welds, and further details can be found in the work of Ilman [26].

\subsection{Interrupted quench experiments}

The nucleation and growth processes during the development of the weld metal microstructure were studied using interrupted quench experiments. Specimens were machined 
Fig. 1 Dilatation curve of a C-Mn steel weld during continuous cooling

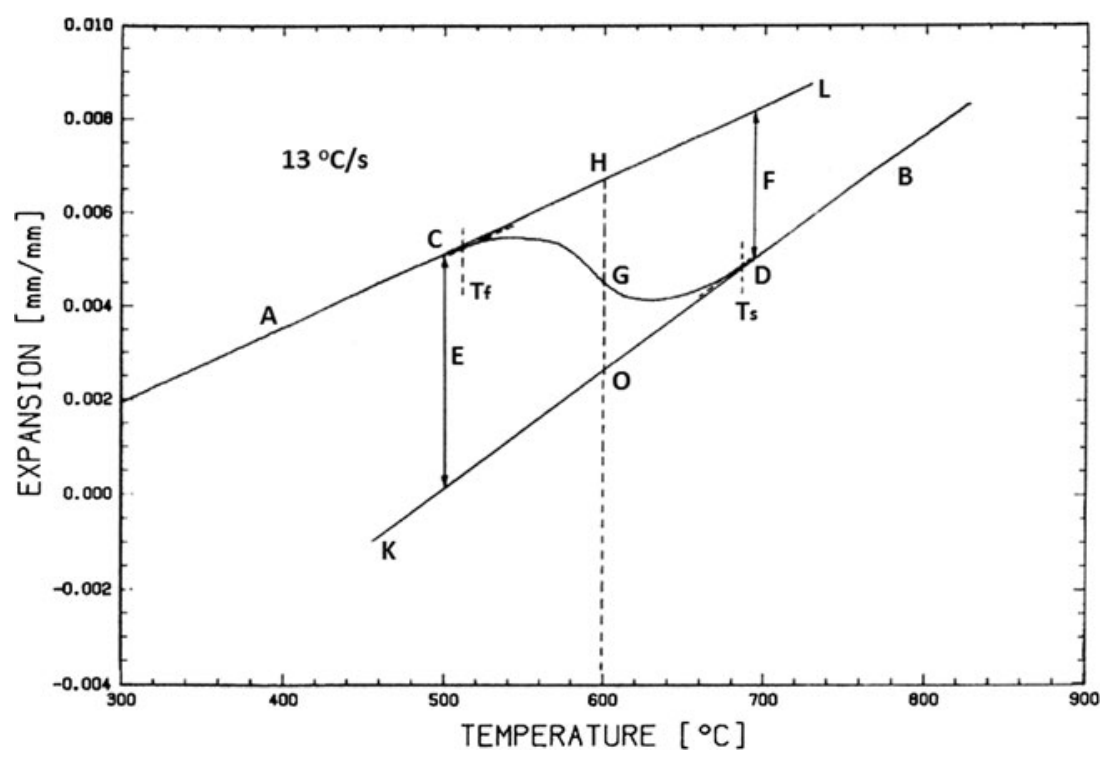

in the form of solid cylinder with the diameter of $3 \mathrm{~mm}$ and $5 \mathrm{~mm}$ in length. A K-type thermocouple was welded at a traverse section of each solid cylinder specimen using a spot welder to monitor temperature during thermal cycle. Specimens were heated in a furnace for $2 \mathrm{~min}$ at $1,250{ }^{\circ} \mathrm{C}$ to reach austenite phase field. Subsequently, the specimens were withdrawn from the furnace to cool in the atmosphere, whilst the temperature was monitored by means of thermocouple attached to the specimens. On reaching temperatures in the range 650 and $720^{\circ} \mathrm{C}$, but typically 700 and $630^{\circ} \mathrm{C}$, the specimens

Fig. 2 As-deposited weld metals: a $\mathrm{O}, \mathbf{b} \mathrm{X}, \mathbf{c} \mathrm{O} 2$ and $\mathbf{d} \mathrm{X} 2$

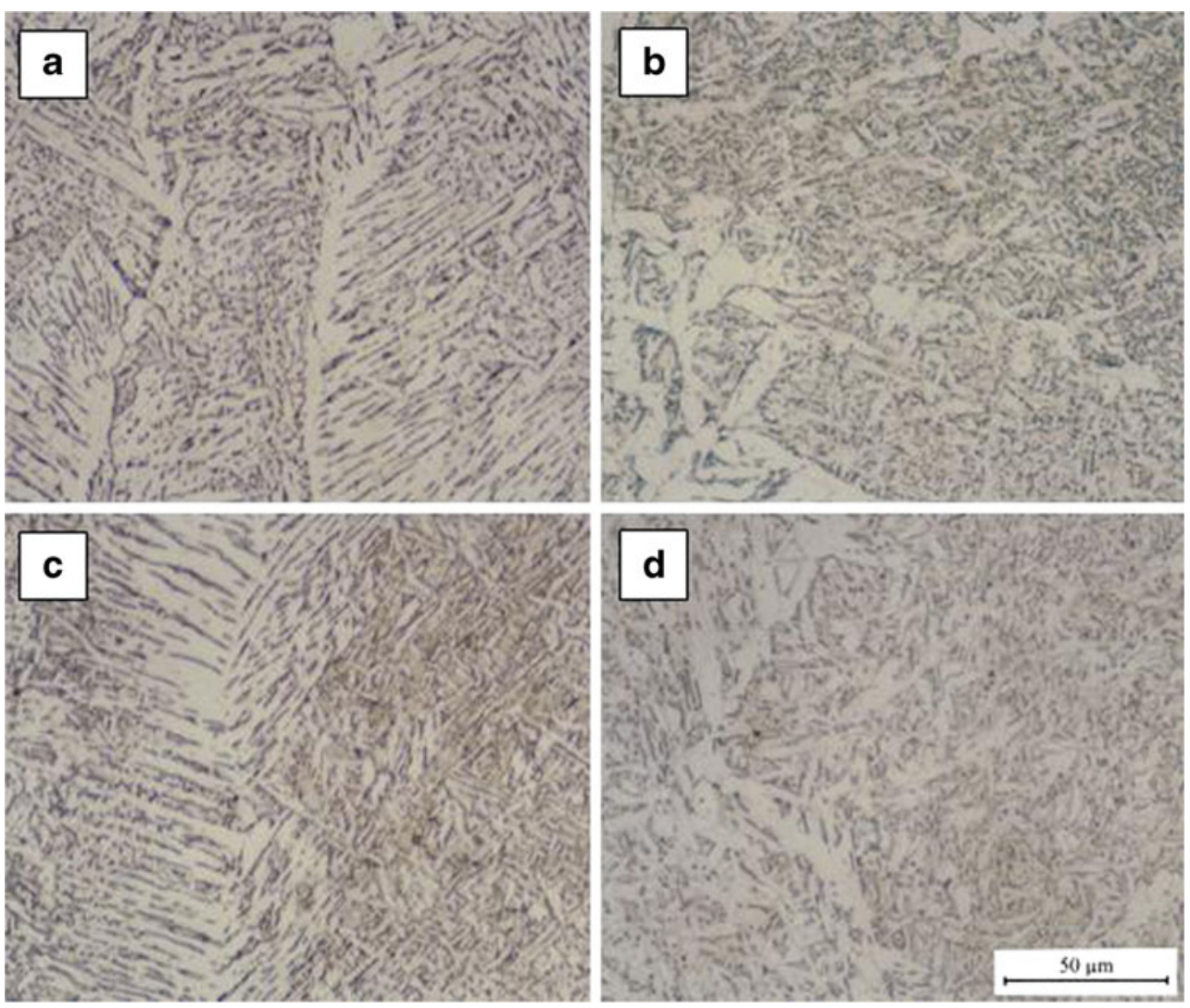


Fig. 3 An example of inclusions in a Ti-free $\mathrm{C}-\mathrm{Mn}$ weld metal
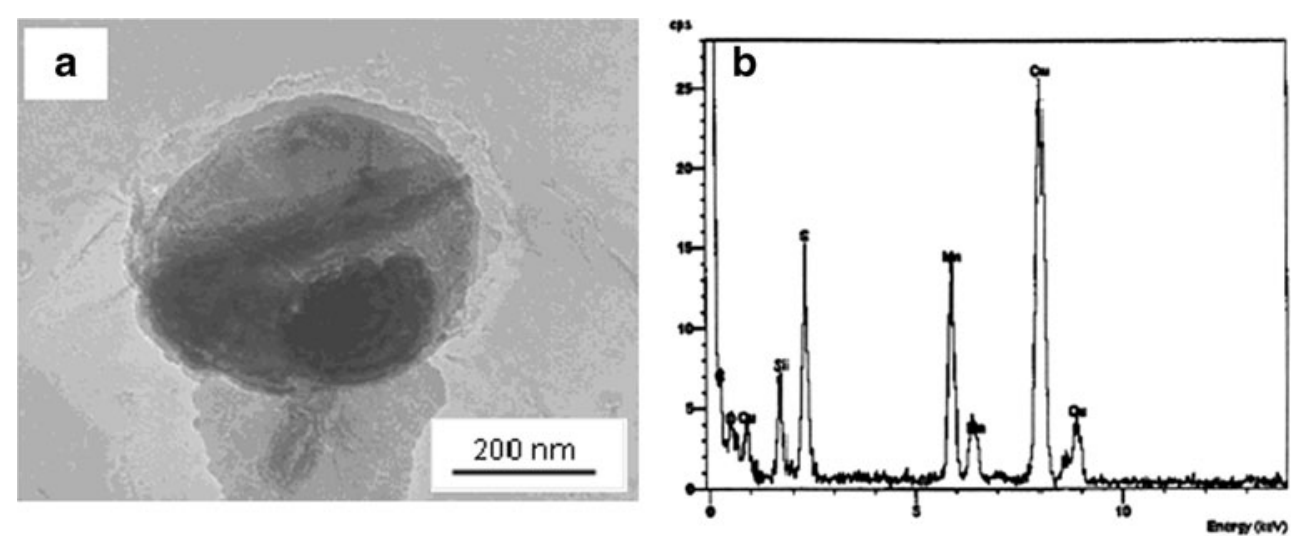

were quenched into water to obtain partially transformed microstructures, and typically, the quench rate was in excess of $200{ }^{\circ} \mathrm{C} / \mathrm{s}$, which is sufficiently fast to arrest ferrite growth. A similar treatment was also applied to synthetic alloys, but after reaching $630{ }^{\circ} \mathrm{C}$ from austenite temperature, the samples were held isothermally at this temperature for $30 \mathrm{~s}$ prior to water quenching.

\subsection{Metallography}

Microstructural examinations were carried out on transverse sections of the weld metals using standard metallographic technique including mounting, grinding, polishing and etching in $2 \%$ nital. Microanalysis of inclusions was carried out using the Philips CM20 Transmission Electron Microscope equipped with an energy-dispersive X-ray spectrometer. Specimens were prepared using carbon extraction replicas to characterise inclusions.

\section{Results and discussion}

The microstructural examination is focused on top beads of all the weld metals under study following the current guidelines proposed by IIW [17, 27]. Figure 2 shows microstructural changes due to different levels of $\mathrm{Ti}$ and $\mathrm{N}$ contents. It can be seen that with a low level of N, a C-Mn steel weld metal coded $\mathrm{O}$ consists mainly of Widmanstatten ferrite which occupies columnar grains. The addition of titanium of around 400 ppm to C-Mn weld metal produced a weld metal, X, with the microstructure completely changed to acicular ferrite. An increase in nitrogen content to a level of $240 \mathrm{ppm}$, designated as $\mathrm{O} 2$ and $\mathrm{X} 2$, does not modify the microstructure significantly, although the acicular ferrite volume fraction appears to be raised slightly, and the average lath dimensions are somewhat refined.

The changes in $\mathrm{C}-\mathrm{Mn}-\mathrm{Ti}-\mathrm{N}$ weld metal microstructure may be related to the nature of inclusions. Microanalysis results, such as those in Fig. 3, of inclusions present in the titanium-free $\mathrm{C}-\mathrm{Mn}$ steel weld metals show that elements present in inclusions are typically $\mathrm{Mn}, \mathrm{Si}$ and $\mathrm{O}$, whereas $\mathrm{S}$ is often observed on inclusion surface. This type of inclusion would be manganese silicate $\left(\mathrm{MnOSiO}_{2}\right)$ which is consistent with a previous report [18]. Elements such as $\mathrm{S}$ and $\mathrm{Cu}$ are often identified in the inclusions probably in the form of $\mathrm{MnS}$ and/or CuS. Figure 4 shows nucleation of acicular ferrite on inclusion with the microanalysis results. The addition of $400 \mathrm{ppm}$ Ti to the $\mathrm{C}-\mathrm{Mn}$ steel weld metals modifies the inclusion chemistry with $\mathrm{Ti}$ and $\mathrm{O}$ present as the principal elements at the expense of $\mathrm{Mn}$ and $\mathrm{Si}$. In general, the inclusions
Fig. 4 Nucleation of acicular on $\mathrm{TiO}$ inclusion in a C-Mn-Ti weld metal
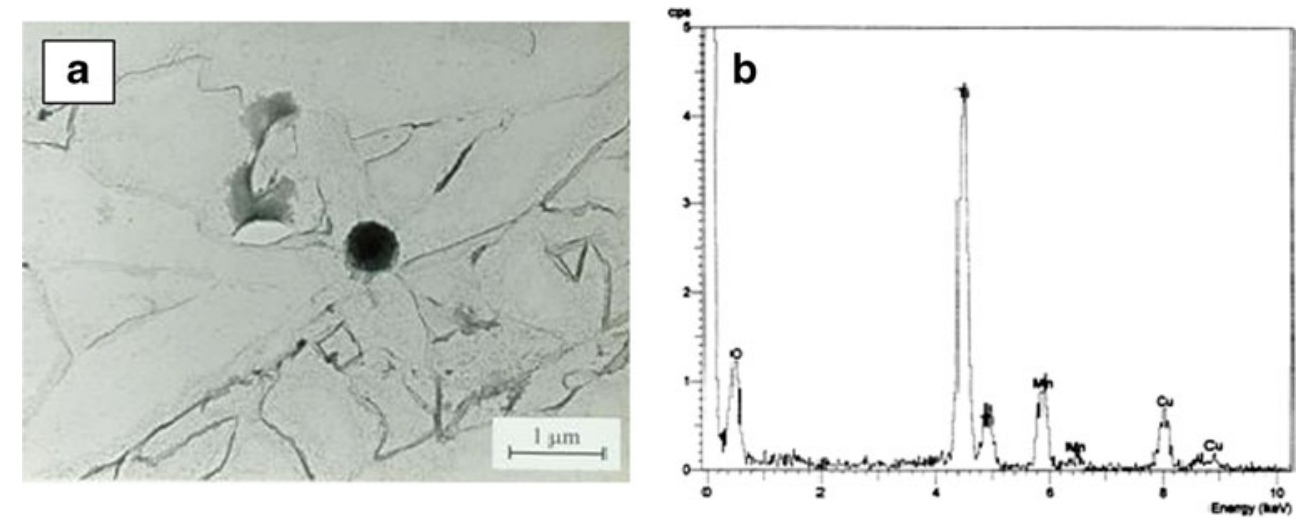
under study appear to be homogeneous with no distinct phase boundaries.

The normal sequence of Ti deoxidation is for the more stable oxides, such as $\mathrm{Ti}_{3} \mathrm{O}_{5}$ or $\mathrm{TiO}_{2}$, to form first, as determined by Babu et al. [28] and Hong et al. [29], but TiO is more likely, as the reaction temperature and oxygen content decrease. However, this will only be true under conditions close to equilibrium and when the oxygen content changes relatively slowly with time and temperature. Obviously, in weld metals, these latter conditions do not apply, and it is more likely that $\mathrm{TiO}$ would predominate at the much more rapid cooling rates prevailing during weld pool solidification. Whilst not observed in this study, it is possible that there is some precursor nucleation of the higher Ti oxides in the molten weld pool which are subsequently enveloped by $\mathrm{TiO}$ as temperature decreases. Such observations were made by Talas [30] during cooling on some 'synthetic' weld metals during simulated TIG arc welding. This study showed that holding a synthetic weld metal initially containing only $\mathrm{Fe}$ $0.16 \% \mathrm{Ti}$ and 600 to $800 \mathrm{ppm} \mathrm{O}$, the only oxides formed after a 5 -s hold in the molten state were $\mathrm{Ti}_{2} \mathrm{O}_{3}$ or $\mathrm{TiO}_{2}$ or complex inclusions consisting or mixtures of these with TiO. As the holding time was increased, more of the inclusions contained only $\mathrm{TiO}$ and TiN were also formed. At these longer times, the oxygen content had reduced to around $200 \mathrm{ppm}$. Although these weld metals contained only trace amounts of $\mathrm{C}$ $(<0.005 \%)$, there was a change in the microstructure from largely massive or quasi-polygonal ferrite at $5 \mathrm{~s}$ to one consisting of carbon-free acicular ferrite or bainite laths. Similar 'cored' weld metals inclusions have been observed in other weld metals, implying that nucleation of one phase on another (such as $\mathrm{TiN}$ on $\mathrm{Al}_{2} \mathrm{O}_{3}$ ) is favoured by rapid cooling. Therefore,
Table 2 Transformation temperatures of $\mathrm{C}-\mathrm{Mn}-\mathrm{Ti}-\mathrm{N}$ weld metals

\begin{tabular}{|c|c|c|c|c|c|c|c|c|}
\hline \multirow[t]{3}{*}{ Weld metal } & \multicolumn{8}{|c|}{ Cooling rate } \\
\hline & \multicolumn{4}{|c|}{$13{ }^{\circ} \mathrm{C} / \mathrm{s}$} & \multicolumn{4}{|c|}{$25^{\circ} \mathrm{C} / \mathrm{s}$} \\
\hline & $T_{\mathrm{s}}$ & $T_{50}$ & $T_{\text {PRTT }}$ & $T_{\mathrm{f}}$ & $T_{\mathrm{s}}$ & $T_{50}$ & $T_{\text {PRTT }}$ & $T_{\mathrm{f}}$ \\
\hline \multicolumn{9}{|l|}{$\mathrm{N}$} \\
\hline $\mathrm{O}$ & 762 & 658 & 650 & 554 & 738 & 644 & 638 & 520 \\
\hline $\mathrm{X}$ & 760 & 660 & 630 & 568 & 740 & 672 & 630 & 562 \\
\hline \multicolumn{9}{|l|}{$\mathrm{N} 2$} \\
\hline $\mathrm{O} 2$ & 754 & 630 & 606 & 534 & 736 & 644 & 635 & 550 \\
\hline $\mathrm{X} 2$ & 760 & 650 & 638 & 572 & 738 & 638 & 634 & 580 \\
\hline
\end{tabular}

it seems likely that the presence of $\mathrm{TiO}$ favours the formation of an acicular ferrite microstructure.

Transformation kinetics of $\mathrm{C}-\mathrm{Mn}-\mathrm{Ti}-\mathrm{N}$ steel weld metals continuously cooled at the rate of $13{ }^{\circ} \mathrm{C} / \mathrm{s}$ are shown in Fig. 5, with the transformation temperatures given in Table 2. There is no significant change in terms of transformation $T_{\mathrm{s}}$, i.e. all weld metals start to nucleate around $760^{\circ} \mathrm{C}$, suggesting that $\mathrm{Ti}$ and soluble $\mathrm{N}$ do not influence the nucleation and growth of grain boundary ferrite. It is interesting to note that the growth of grain boundary ferrite is characterised by the presence of 'kinks' at the early stage of transformation in a good agreement with the work of Cochrane [31] and theoretical expectations that transformation starts at austenite grain boundaries and rapidly consumes those available sites before transformation starts in the grain interiors.

The kinetics of austenite to ferrite transformation may be compared from the gradient of fraction transformed (f)temperature $(T)$ plots giving $\mathrm{df} / \mathrm{dT}$ or transformation rate,
Fig. 5 Transformation kinetics of $\mathrm{C}-\mathrm{Mn}-\mathrm{Ti}-\mathrm{N}$ steel weld metal at the cooling rate of $13{ }^{\circ} \mathrm{C} / \mathrm{s}$

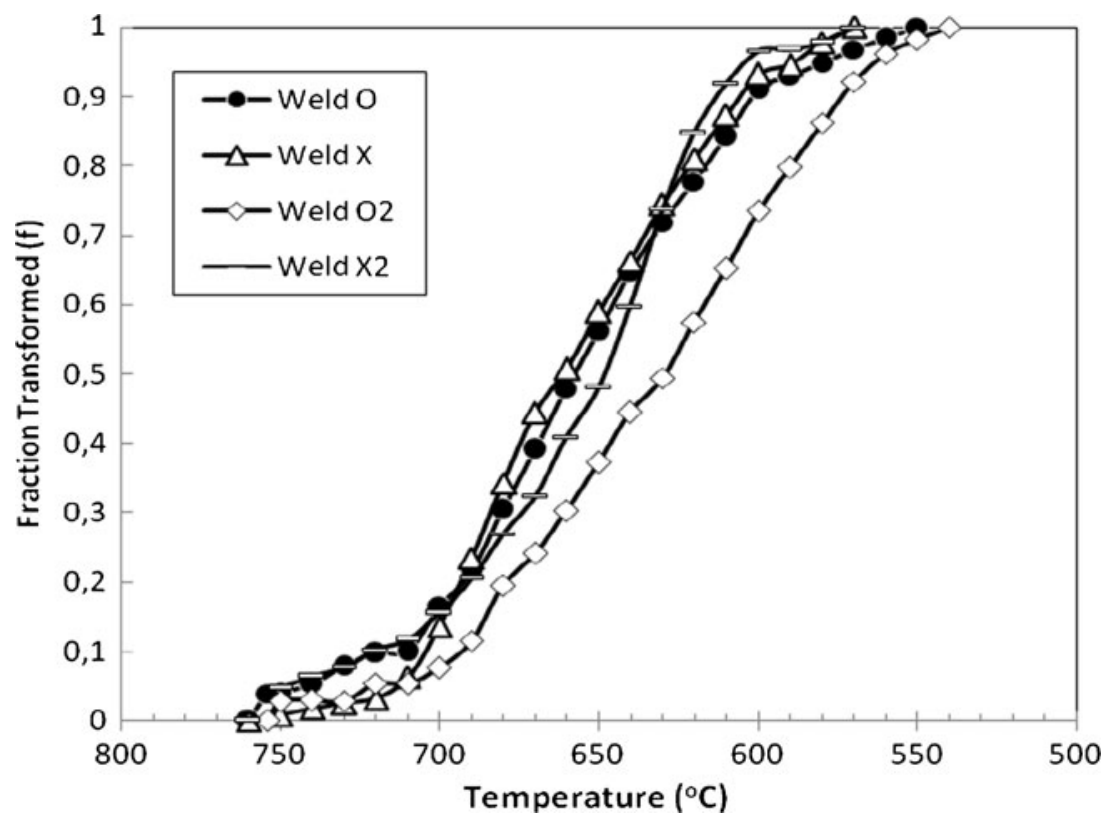


Fig. 6 Transformation kinetics of $\mathrm{C}-\mathrm{Mn}-\mathrm{Ti}-\mathrm{N}$ steel weld metal at the cooling rate of $25^{\circ} \mathrm{C} / \mathrm{s}$

Fig. 7 Microstructure of weld metals $\mathrm{O}$ and $\mathrm{X}$ quenched from 700,630 and $600{ }^{\circ} \mathrm{C}$
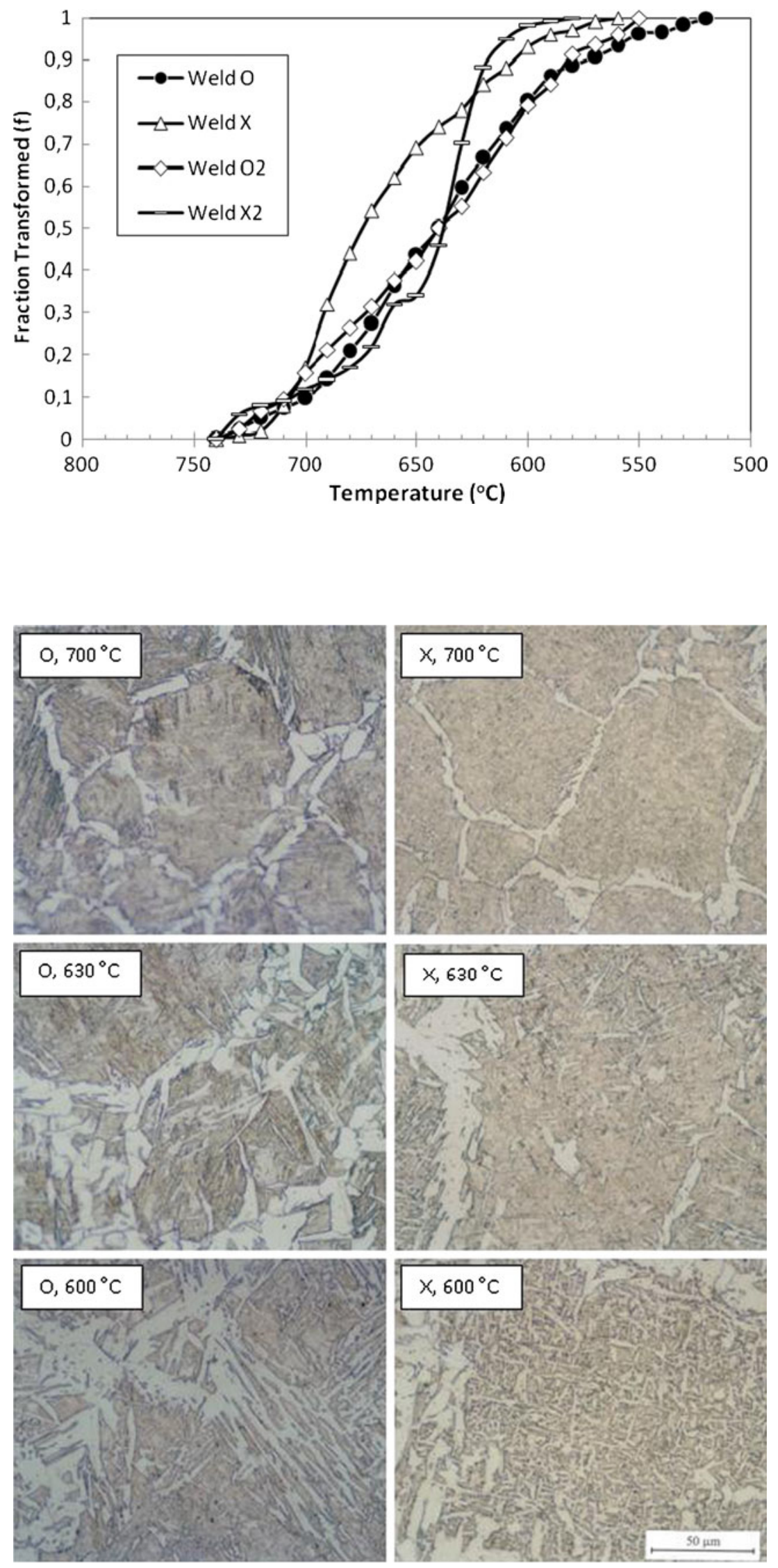
Fig. 8 Microstructure. a As-cast $\mathrm{C}-\mathrm{Mn}-\mathrm{Ti}$ steel, $\mathbf{b}$ as-cast $\mathrm{C}-\mathrm{Mn}-$ $\mathrm{Ti}-\mathrm{N}$ and $\mathbf{c} \mathrm{C}-\mathrm{Mn}-\mathrm{Ti}-\mathrm{N}$ quenched from $630{ }^{\circ} \mathrm{C}$ after austenitisation at $1,250^{\circ} \mathrm{C}$ for $2 \min$
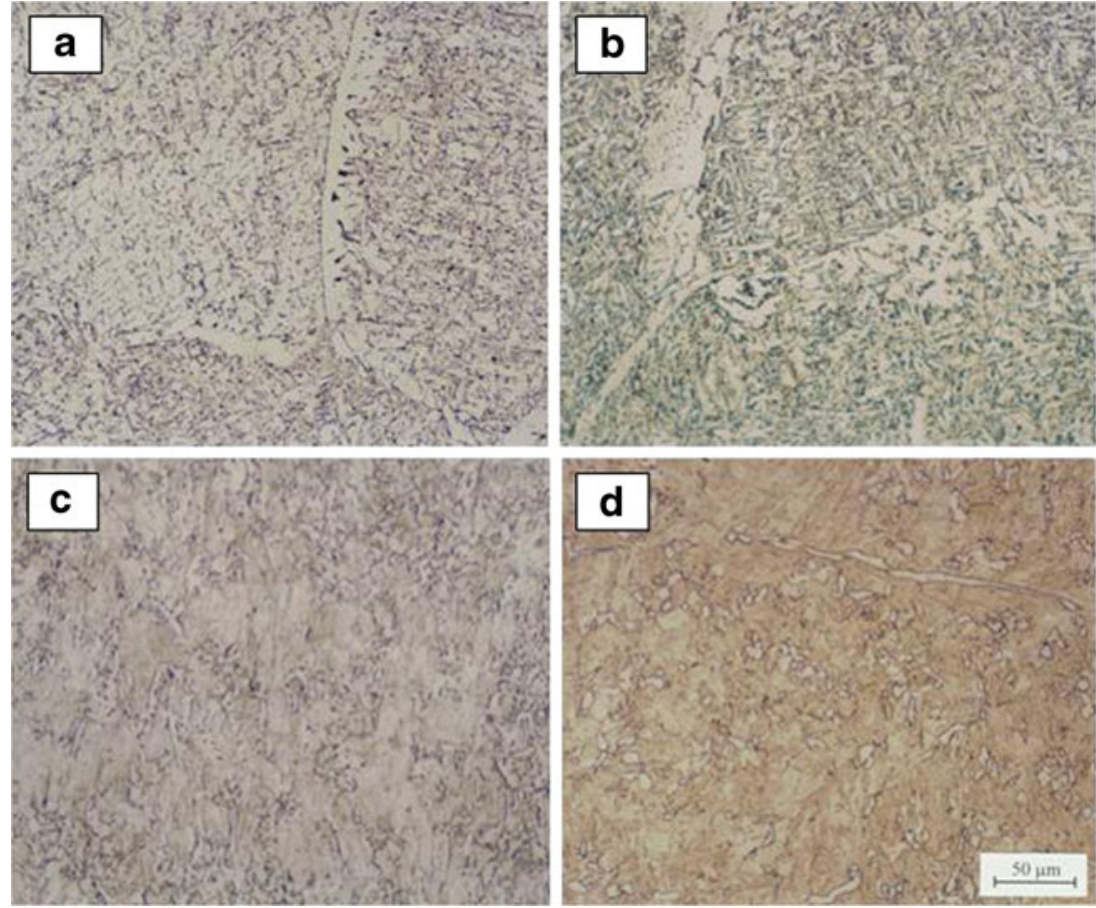

at any given temperature. The transformation reaction of titanium-free $\mathrm{C}-\mathrm{Mn}$ steel weld metals, namely, $\mathrm{O}$ and $\mathrm{O} 2$ occurs at very slow rates, and the fraction of austenite transformed to ferrite increases more gradually with decreasing
Fig. 9 a Nucleation ferrite on TiN precipitate. $\mathbf{b}$ Spectra of precipitate. c Selected area diffraction pattern (SADP) of precipitate with the corresponding interpreted SADP (d)
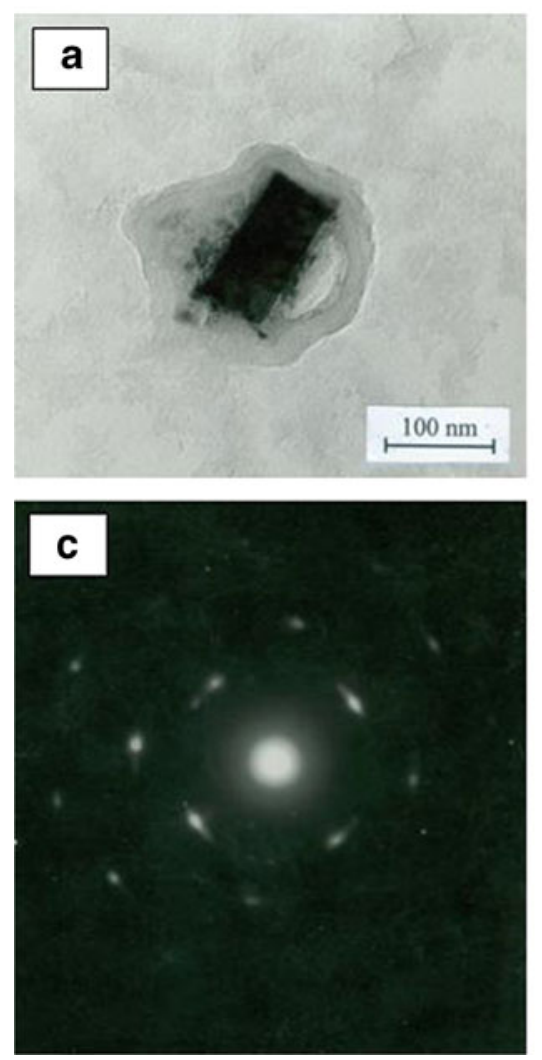

d

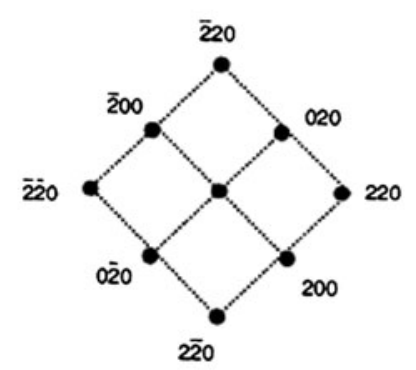

[001] 
temperature than when Ti is present. As a result, the transformation finishes at lower temperatures. In contrast, transformation kinetics of titanium-containing weld metals $\mathrm{X}$ and $\mathrm{X} 2$ occur at faster rates. These higher transformation rates appear to be associated with the development of intragranularly nucleated acicular ferrite. The rationale for this lies in the various models for acicular ferrite growth; this microstructure forms by rapid nucleation at intragranular sites in the austenite, and since there are many such sites, mainly at inclusions, nucleation is increased, and hence, transformation is accelerated.

The effects of cooling rate can be seen by comparing the weld metals continuously cooled at the rate of $13^{\circ} \mathrm{C} / \mathrm{s}$ (Fig. 5, Table 3 in Appendix) and the ones with the cooling rate of $25{ }^{\circ} \mathrm{C} / \mathrm{s}$ (Fig. 6, Table 4 in Appendix). The cooling rates used in this study fall in the range of actual weld cooling rates, typically $1-30{ }^{\circ} \mathrm{C} / \mathrm{s}[32,33]$. It can be seen that an increase in cooling rate lowers the transformation-start temperature for all weld metals and accelerates the development of acicular ferrite in welds $X$ and $X 2$, but more markedly in $X$. As a result, the amount of acicular ferrite increases at the expense of grain boundary ferrite.

The sequence of microstructural development in $\mathrm{C}-\mathrm{Mn}-\mathrm{Ti}-$ $\mathrm{N}$ weld metals (weld $\mathrm{O}$ and $\mathrm{X}$ ) can be assessed from the results of interrupted quench experiments as shown in Fig. 7. At $700{ }^{\circ} \mathrm{C}$, both weld metals show a large amount of welldeveloped grain boundary ferrite along prior austenite grain boundaries. At the lower temperature of $630^{\circ} \mathrm{C}$, Widmanstatten ferrite starts to develop in weld $\mathrm{O}$ by lateral thickening and length-wise growth from austenite grain boundary sites. In contrast, weld metal $\mathrm{X}$ is dominated by the nucleation of intragranular acicular ferrite within the austenite grains. It can be seen that the volume fraction of Widmanstatten ferrite formed at this temperature is lower than that of acicular ferrite. Further cooling down to $600{ }^{\circ} \mathrm{C}$, the growing Widmanstatten ferrite plates in weld $\mathrm{O}$ become longer, and some ferrite plates have already impinged with the other plates, but the transformation is not finished yet, whereas the growth of acicular ferrite in weld $\mathrm{X}$ seems to be complete. Results of this interrupted quench experiment seem to confirm that $\mathrm{MnOSiO}_{2}$ glassy inclusions do not effectively nucleate acicular ferrite in austenite grain interiors, hence allowing Widmanstatten ferrite to form.

Of note is that the amount of oxygen in $\mathrm{C}-\mathrm{Mn}-\mathrm{Ti}-\mathrm{N}$ weld metals under study is maintained constant, typically $300 \mathrm{ppm}$, so that there is sufficient oxygen for the titanium to react to form $\mathrm{TiO}$, hence allowing nitrogen to be present in solid solution. The present investigation failed to find evidence for TiN precipitation in as-deposited $\mathrm{C}-$ $\mathrm{Mn}-\mathrm{Ti}-\mathrm{N}$ weld metals. This is because the formation of TiN is dependent on the reaction sequence as follows: Ti reacts with $\mathrm{O}$, and then, Ti, with $\mathrm{N}$. Provided that the oxygen content is in excess of stoichiometry $(2.81: 1 \mathrm{wt} \%)$ with titanium (as in the weld metal samples), then, thermodynamic equilibrium would favour the formation of $\mathrm{TiO}$ in the liquid phase.

Removing oxygen as in the synthetic alloys strongly indicates an effect of nitrogen on microstructural development. Figure $8 \mathrm{a}$, b shows microstructures of the as-cast $\mathrm{C}-\mathrm{Mn}-\mathrm{Ti}$ alloy without and with nitrogen additions, respectively. It can be seen that the addition of sufficient nitrogen to $\mathrm{C}-\mathrm{Mn}-\mathrm{Ti}$ alloy changes the microstructure from one largely consisting of ferrite side plates to one largely consisting of intragranularly nucleated acicular ferrite. Interrupting the transformation by water quenching from $630{ }^{\circ} \mathrm{C}$ in the oxygen-free $\mathrm{C}-\mathrm{Mn}-\mathrm{Ti}$ alloy (Fig. 8c) shows the nucleation of ferrite side plates, whereas in C-Mn-Ti-N alloy (Fig. 8d), the microstructure is marked by the considerable intragranular nucleation of acicular ferrite within the austenite grains. Carbon extraction replicas taken from this sample provided several examples of nucleation of a spherical cap of ferrite on cubic Ti-rich precipitates, and one such is shown in Fig. 9. This type of precipitate has a fec structure with a lattice parameter of $0.424 \mathrm{~nm}$ which is consistent with TiN.

Results of the present investigation seem to confirm the importance of nitrogen in steel weld metal, and the beneficial effect of nitrogen is obtained by careful addition of nitrogen to $\mathrm{C}-\mathrm{Mn}$ steel weld metals and its interactions with other alloying elements to form TiN. The findings of this study may be relevant to developing nitrogen bearing $\mathrm{C}-\mathrm{Mn}$ steel weld metals with more complex compositions involving strong deoxidisers such as $\mathrm{Al}$ and $\mathrm{Ti}$ and hardenability elements.

\section{Conclusions}

1. The effect of Ti on weld metals containing approximately $300 \mathrm{ppm}$ oxygen is to cause a change in a microstructure from one consisting of Widmanstatten side plates to one of acicular ferrite.

2. Transformation studies show that the kinetics of transformation are similarly changed, and the rate of transformation is higher for the acicular ferrite structures.

3. Although there was evidence for nucleation of acicular ferrite at $\mathrm{TiO}$ inclusions in the weld metals studied, the evidence for the effect of nitrogen on microstructure was not consistent with the presence of TiN particles.

4. On the other hand, studies of a synthetic alloy containing little or no oxygen confirmed that ferrite nucleation at intergranular sites could occur on TiN particles.

5. It is concluded that these findings illustrate the possibility of using nitrogen as a deliberate alloying addition, and under some circumstances, nitrogen additions may be beneficial.

Open Access This article is distributed under the terms of the Creative Commons Attribution License which permits any use, distribution, and reproduction in any medium, provided the original author(s) and the source are credited. 


\section{Appendix}

Table 3 Dilatometric data for welds $\mathrm{O}, \mathrm{X}, \mathrm{O} 2$ and X2 at the cooling rate of $13{ }^{\circ} \mathrm{C} / \mathrm{s}$

Cooling rate $\left(13^{\circ} \mathrm{C} / \mathrm{s}\right)$

\begin{tabular}{lllll}
\hline Temperature $\left({ }^{\circ} \mathrm{C}\right)$ & \multicolumn{4}{l}{ Fraction transformed $(f)$} \\
\cline { 2 - 5 } & $\mathrm{O}$ & $\mathrm{X}$ & $\mathrm{O} 2$ & $\mathrm{X} 2$ \\
\hline
\end{tabular}

510

520

530

540

550

560

570

580

590

600

610

620

630

640

650

660

670

680

690

700

710

720

730

740

750

754

760

765

\begin{tabular}{|c|c|c|c|}
\hline & & 1 & \\
\hline 1 & & 0.9818 & \\
\hline 0.9839 & & 0.9623 & \\
\hline 0.9681 & 1 & 0.9223 & 1 \\
\hline 0.9492 & 0.978 & 0.8627 & 0.978 \\
\hline 0.9298 & 0.9457 & 0.798 & 0.967 \\
\hline 0.9107 & 0.932 & 0.7347 & 0.966 \\
\hline 0.8426 & 0.8736 & 0.6526 & 0.9195 \\
\hline 0.7778 & 0.81 & 0.5745 & 0.847 \\
\hline 0.7184 & 0.7439 & 0.4945 & 0.7381 \\
\hline 0.6471 & 0.663 & 0.4445 & 0.598 \\
\hline 0.5612 & 0.5897 & 0.3721 & 0.4815 \\
\hline 0.4792 & 0.507 & 0.3023 & 0.41 \\
\hline 0.3913 & 0.4444 & 0.241 & 0.3247 \\
\hline 0.3043 & 0.343 & 0.1951 & 0.27 \\
\hline 0.2159 & 0.2353 & 0.1154 & 0.2055 \\
\hline 0.1628 & 0.136 & 0.0769 & 0.155 \\
\hline 0.1 & 0.0625 & 0.0533 & 0.1159 \\
\hline 0.0976 & 0.032 & 0.0541 & 0.103 \\
\hline 0.0779 & 0.025 & 0.0286 & 0.0758 \\
\hline 0.0526 & 0.018 & 0.0294 & 0.063 \\
\hline 0.0417 & 0.008 & 0.0273 & 0.0469 \\
\hline 0.0389 & 0.003 & 0 & 0.0283 \\
\hline 0 & 0 & & 0 \\
\hline
\end{tabular}

Table 4 Dilatometric data for welds $\mathrm{O}, \mathrm{X}, \mathrm{O} 2$ and $\mathrm{X} 2$ at the cooling rate of $25^{\circ} \mathrm{C} / \mathrm{s}$

Cooling rate $\left(25^{\circ} \mathrm{C} / \mathrm{s}\right)$

\begin{tabular}{llcll}
\hline Temperature $\left({ }^{\circ} \mathrm{C}\right)$ & \multicolumn{4}{l}{ Fraction transformed $(f)$} \\
\cline { 2 - 5 } & $\mathrm{O}$ & $\mathrm{X}$ & $\mathrm{O} 2$ & $X 2$
\end{tabular}

\begin{tabular}{ll}
\hline 500 & \\
520 & 1 \\
530 & 0.982 \\
540 & 0.964 \\
550 & 0.963
\end{tabular}

Table 4 (continued)

Cooling rate $\left(25^{\circ} \mathrm{C} / \mathrm{s}\right)$

\begin{tabular}{|c|c|c|c|c|}
\hline \multirow[t]{2}{*}{ Temperature $\left({ }^{\circ} \mathrm{C}\right)$} & \multicolumn{4}{|c|}{ Fraction transformed $(f)$} \\
\hline & $\mathrm{O}$ & $\mathrm{X}$ & $\mathrm{O} 2$ & $X 2$ \\
\hline 560 & 0.933 & 1 & 0.958 & \\
\hline 570 & 0.906 & 0.99 & 0.935 & \\
\hline 580 & 0.885 & 0.97 & 0.911 & 1 \\
\hline 590 & 0.863 & 0.96 & 0.841 & 0.99 \\
\hline 600 & 0.8 & 0.93 & 0.791 & 0.98 \\
\hline 610 & 0.735 & 0.88 & 0.714 & 0.95 \\
\hline 620 & 0.667 & 0.84 & 0.634 & 0.88 \\
\hline 630 & 0.596 & 0.78 & 0.55 & 0.7 \\
\hline 640 & 0.5 & 0.74 & 0.5 & 0.46 \\
\hline 650 & 0.439 & 0.69 & 0.421 & 0.34 \\
\hline 660 & 0.364 & 0.62 & 0.378 & 0.32 \\
\hline 670 & 0.275 & 0.54 & 0.314 & 0.22 \\
\hline 680 & 0.209 & 0.44 & 0.265 & 0.17 \\
\hline 690 & 0.143 & 0.32 & 0.212 & 0.14 \\
\hline 700 & 0.098 & 0.17 & 0.156 & 0.12 \\
\hline 710 & 0.075 & 0.08 & 0.097 & 0.09 \\
\hline 720 & 0.051 & 0.02 & 0.067 & 0.08 \\
\hline 730 & 0.026 & 0.01 & 0.026 & 0.06 \\
\hline 740 & 0 & 0 & 0 & 0 \\
\hline 750 & & & & \\
\hline
\end{tabular}

\section{References}

1. Mori N, Homma H, Ohkita S, Asano K (1980) The behaviour of B and $\mathrm{N}$ in notch toughness improvement of Ti-B bearing weld metals. American Welding Society, Miami, IIW/ISS-IX-1158-80

2. Homma H, Ohkita S, Matsuda S, Yamamoto K (1987) Improvement of HAZ toughness in HSLA steel by introducing finely dispersed Ti-oxide. Weld J 66:301-309

3. Thewlis G (1994) Transformation kinetics of ferrous weld metal. Mater Sci Technol 10:110-125

4. Cochrane RC, Senogles DJ (1997) The effect of Ti additions on the microstructure of autogenous laser welds. In: Baker TN (ed) Titanium technology in microalloyed steels: proceedings of a conference held at the University of Sheffield, December 1994. The Institute of Materials, Cambridge, pp 207-223

5. Mills AR, Thewlis G, Whiteman JA (1987) Nature of inclusions in steel weld metals and their influence on formation of acicular ferrite. Mater Sci Technol 3:1051-1061

6. Jang J, Indeacochea JE (1987) Inclusion effects on submerged arc weld microstructure. J Mater Sci 22:689-700

7. Grong O, Matlock DK (1986) Microstructure development in mild and low alloy steel weld metals. Int Metal Rev 31:27-48

8. Yamada T, Terasaki H, Komizo Y (2009) Relation between inclusion surface and acicular ferrite in low alloy steel weld. ISIJ Int 49(27):1059-1062

9. Powel GLF, Lloyd PG, Bee JV (1998) Heterogeneity of coarsened oxide inclusions in C-Mn steel welds. Sci Technol Weld Join 3(1):9-11 
10. Byun JS, Shim JH, Chou WC (2003) Influence of Mn on microstructural evolution in Ti-killed C-Mn steel. Scr Mater 48:449-454

11. Yamamoto K, Hasegawa T, Takamura J (1996) Effect of boron on intragranular ferrite formation in Ti-oxide bearing. ISIJ Int 36(1):80-86

12. Ito Y, Nakanishi M (1975) Study on Charpy impact properties of weld metal with submerged arc welding. IIW. IIW document, XII-113-75

13. Mori N, Homma H, Okita S, Wakabayashi M (1981) Mechanism of $\mathrm{B}$ and $\mathrm{N}$ of notch toughness improvement in Ti-B bearing weld metals. IIW. IIW document IX-1196-81

14. Lau TW, Sadowski MM, North TH, Weatherly GC (1988) Effect of nitrogen on properties of submerged arc weld metal. Materials Science and Technology 4(1):53-61

15. Lee SY, Oh YJ, Yi KW (2002) Effect of titanium and oxygen content on microstructure in low carbon steels. Mater Trans 43(3):518-522

16. Ohkita S, Horii Y (1995) Recent development in controlling the microstructure and properties of low alloy steel weld metals. ISIJ Int 35(10):1170-1182

17. Evans GM (1993) The effect of titanium on the microstructure and properties of C-Mn all weld metal deposits. Weld J 72(3):123-134s

18. Blais C, Esperance GL, Evans GM (1999) Characterisation of inclusion found in C-Mn steel welds containing titanium. Sci Technol Weld Join 4(3):143-150

19. Poulalion A, Botte R (1988) Nitrogen addition in steelmaking using nitriding ferroalloys. The Institute of Metals, Lille, pp 49-52, Proceedings of the international conference on high nitrogen steels

20. Achar DR, Kocak M, Evans GM (1998) Effect of nitrogen on toughness and strain age embrittlement of ferritic steel weld metal. Sci Technol Weld Join 3(5):233-243

21. Evans GM (1998) Effect of nitrogen on C-Mn steel welds containing titanium and boron. Weld J 77:239s-248

22. Bang KS, Kim WY, Park C (2007) Effects of nitrogen on weld metal microstructure and toughness in submerged arc welding. Materials Science Forum 539-543:3906-3911
23. Oldland RB (1985) The influence of aluminium and nitrogen on the microstructures and properties of single pass submerged arc welds. Monash University, Clayton, pp 44-56

24. Thewlis G, Whiteman JA, Senogles D (1997) Dynamics of austenite to ferrite phase transformation in ferrous weld metals. Materials Science and Technology 13(3):257-274

25. Abson DJ, Pargeter RJ (1986) Factors influencing strength, microstructure and toughness of as deposited manual metal arc welds suitable for C-Mn steel fabrications. Int Metal Rev 31(4):141-193

26. Ilman MN (2001) The development of acicular ferrite in C-Mn steel weld metals containing Ti, B Al and N. University of Leeds, Leeds, $\mathrm{Ph} . \mathrm{D}$. thesis

27. IIW/IIS (1986) Guidelines for classification of ferritic steel weld metal microstructural constituents using the light microscope. Welding in the World 24(7/8):144-149

28. Babu SS, David SA, Vitek JM, Mundra K, DebRoy T (1995) Development of macro- and microstructures of carbon-manganese low alloy steel welds: inclusion formation. Mater Sci Technol 11:186-199

29. Hong T, Pitscheneder W, DebRoy T (1998) Quantitative modelling of motion, temperature gyrations, and growth of inclusions in weld pool. Sci Technol Weld Join 3(1):33-41

30. Talas S (2001) Ferrite morphology in powder compacted Fe-TiMn-C synthetic weld metals. University of Leeds, Leeds, Ph.D. thesis

31. Cochrane RC (1984) British steel technical report. Unpublished

32. Harrison PL, Farrar RA (1981) Influence of oxygen-rich inclusions on the $\gamma \rightarrow \alpha$ phase transformation in high strength low alloy (HSLA) steel weld metals. J Mater Sci 16:2218-2226

33. Farrar RA, Zhang Z (1993) Experimental verification of the continuous cooling transformation diagram produced by the dilatometrymetallography method. J Mater Sci Lett 12:1606-1611 